\title{
Agronomic Biofortification of Paddy through Nitrogen, Zinc and Iron Fertilization: A Review
}

\author{
Dipender Kumar $^{\text {1* }}$, S.S. Dhaliwal ${ }^{2}$, R.K.Naresh ${ }^{3}$ and Amit Salaria ${ }^{1}$ \\ ${ }^{1}$ Department of Agronomy, ${ }^{2}$ Department of Soil Sciences, Punjab Agricultural University, \\ Ludhiana, Punjab, India \\ ${ }^{3}$ Department of Agronomy, Sardar Vallabhbhai Patel University of Agricuture and \\ Technology, Meerut, India \\ *Corresponding author
}

\section{A B S T R A C T}

\begin{tabular}{|c|}
\hline Keywords \\
\hline $\begin{array}{l}\text { Biofortification, } \\
\text { Malnutrition, } \\
\text { Nitrogen } \\
\text { fertilization, Soil } \\
\text { and foliar sprays of } \\
\text { micronutrients }\end{array}$ \\
\hline Article Info \\
\hline $\begin{array}{l}\text { Accepted: } \\
20 \text { June } 2018 \\
\text { Available Online: } \\
10 \text { July } 2018\end{array}$ \\
\hline
\end{tabular}

Globally, micronutrient malnutrition alone affecting more than two billion people, mostly among resource-poor families in developing countries, with $\mathrm{Zn}$, Fe, I and vitamin A deficiencies most prevalent. Approximately, five million children dies micronutrient malnutrition every year. Currently, micronutrient malnutrition is considered to be the most serious threat and global challenge to human kind and it is avoidable. Among different micronutrients, zinc and iron deficiency is a well-documented problem in food crops due to which crop yields and nutritional quality decreases. Generally, the regions in the world with $\mathrm{Zn}$-deficient soils are also characterized by widespread $\mathrm{Zn}$ deficiency in humans. Current trend indicate that nearly half of world population suffers from $\mathrm{Zn}$ and Fe deficiency. Cereal crops mainly rice which play an important role in satisfying daily calorie intake in developing world, but they are inherently very low in $\mathrm{Zn}$ and Fe concentrations in grain. It provides $21 \%$ of energy and $15 \%$ of protein requirements but does not provide essential micronutrients i.e. Zn and Fe to eliminate their deficiencies. So, the enrichment of rice with $\mathrm{N}, \mathrm{Zn}$ and Fe fertilization can solve the problem of $\mathrm{Zn}$ and Fe deficiencies, which are two amongst the most serious nutritional problems affecting human beings. Among the strategies being discussed as major solution to $\mathrm{Zn}$ and Fe deficiency with the use different modes of fertilizers, agronomic biofortification appears to be a most sustainable and cost-effective approach useful in improving $\mathrm{Zn}$ and $\mathrm{Fe}$ concentrations in grain. Scientific evidences show this is technically feasible without compromising agronomic productivity.

\section{Introduction}

Rice (Oryza sativa L.) is a self pollinated, short day plant belonging to the family Poaceae and it is the cereal crop with the second highest worldwide production. Rice is the dominant staple food for more than half of the world's population (Wang et al., 2005). It is grown in more than 100 countries, predominantly in Asia. Rice provides $21 \%$ of energy and $15 \%$ of protein requirements of human populations globally (Depar et al., 2011). It provides $23 \%$, more than that provided by wheat and corn, of all the calories 
consumed by the world's population, and even provides $50-80 \%$ of the energy intake of the people in developing countries but it does not provide enough essential micronutrients to eliminate zinc ( $\mathrm{Zn})$ and iron (Fe) deficiency (IRRI, 2006). Rice, however, is a poor source of many essential mineral nutrients, especially $\mathrm{Zn}$ and $\mathrm{Fe}$ for human nutrition. The polished rice contains on an average only $12 \mathrm{mg} \mathrm{kg}^{-1} \mathrm{Zn}$ and $2 \mathrm{mg} \mathrm{kg}^{-1} \mathrm{Fe}$ whereas the recommended dietary intake of $\mathrm{Zn}$ for people is $12-15 \mathrm{mg}$ and that of $\mathrm{Fe}$ is $10-15 \mathrm{mg}$ per day (Welch and Graham, 2004). Currently, malnutrition of $\mathrm{Zn}$ and Fe afflicts more than $50 \%$ of the world's population. Heavy and monotonous consumption of rice with low concentrations of $\mathrm{Fe}$ and $\mathrm{Zn}$ has been considered a major reason for $\mathrm{Fe}$ and $\mathrm{Zn}$ malnutrition (Graham et al., 2001). Therefore, a slight increase in its nutritive value would be highly beneficial for alleviation of $\mathrm{Fe}$ and $\mathrm{Zn}$ malnutrition and for human health. Poor grain nutritive value of $\mathrm{Zn}$ and $\mathrm{Fe}$ in cereals is an important reason for widespread micronutrient malnutrition among the populations eating rice, wheat or maize as staple food.

\section{New approaches}

Recently, food based approach 'biofortification' has been recognized as an efficient mean to reduce micronutrient and protein malnutrition. Biofortification is a scientific method for improving the nutritional value of foods already consumed by those suffering from hidden hunger. It involves the development of functional staple food crops that are selectively bred to enhance specific nutritional qualities, such as the levels of biologically available $\mathrm{Zn}$ and Fe. Biofortification complements other interventions and is a means to provide micronutrients to the most vulnerable people in a comparatively inexpensive and costeffective way, using an agricultural intervention that is sustainable (Pfeiffer and
McClafferty, 2007). Broadley et al., (2006) revealed that agronomic biofortification strategy has been suggested as a promising way for enriching cereal grains in UK. Likewise, agronomic biofortification is economically sustainable and practically adoptable solution to overcome the $\mathrm{Zn}$ deficiency issue in rice (Qamar et al., 2017). Cakmak (2008) reported that severe human health problem in mind; science as well as the agrochemical industry together with the farmers is forced to find practicable and cost- effective solutions to improve the $\mathrm{Zn}$ status of human beings in the areas affected by $\mathrm{Zn}$ deficiency. He also reported that low dietary intake of $\mathrm{Zn}$ and $\mathrm{Fe}$ appears to be the major reason for the widespread prevalence of $\mathrm{Zn}$ and $\mathrm{Fe}$ deficiencies in human populations.

Several methods are used to solve micronutrients deficiencies such as micronutrient supplementation, food fortification, soil application, coating seed with Fe, soaking of seed in micronutrient solution, dipping roots of seedlings in solutions or suspensions, bio-fortification and fertifortification (Nestel et al., 2006). Nitrogen (N) application is the main segment in agronomic biofortification in rice and Gregorio et al., (2000) have reported that $\mathrm{N}$ level is an important factor which determines grain mineral content. However, the effects of $\mathrm{N}$ on $\mathrm{Zn}$ and $\mathrm{Fe}$ concentration in rice grains are not unambiguous, though $\mathrm{N}$ fertilization on increasing nutrient concentration in other crops had been proved to be effective (Wangstrand et al., 2006). Soil application is the most common method and prophylactic in nature whereas, the foliar application with $\mathrm{Fe}$ (Fertifortificaton) are therapeutic in nature. Fertifortification is a technique to increase $\mathrm{Zn}$ and $\mathrm{Fe}$ content in rice grains and brown rice. Bio-fortification and commercial fertifortification, though is a slow process and show low efficiency of nutrient enrichment, but still these are highly complementary. 
Among different techniques to enhance $\mathrm{Zn}$ and $\mathrm{Fe}$ content in rice, agronomic fertifortification may have important spin-off effects for increasing farm productivity enriched with nutrients in developing countries in an environmentally beneficial way.

Zinc and Fe deficiencies that weaken immune system function and may impair growth and development afflict more than $50 \%$ of world population and are widespread in the world, especially in developing countries, where it is estimated that $40-45 \%$ of school-age children are anaemic and that about $50 \%$ of this anaemia results from Fe deficiency. Zinc and Fe deficiency in human is a serious threat not only to the health of individuals but also to the economy of developing nations. Overcoming malnutrition related disorders in the world has been identified as the top priority by a panel of distinguished economists. Micronutrient malnutrition have affected lives of billions as evident by 5 billion suffering from $\mathrm{Fe}$ and 2.7 billion suffering from $\mathrm{Zn}$ deficiency all over the world (ACC/SCN, 2004). In India, 47\% children suffer from protein energy malnutrition (PEM), 74\% children under three years of age, $43 \%$ preschool children, $90 \%$ adolescent girls and 50\% women are having clinical $\mathrm{Fe}$ deficiency and $27 \%$ of total population in India is affected by $\mathrm{Zn}$ deficiency related disorders such as poor immune system, diarrhoea, poor physical and mental growth (WHO, 2007). Zn deficiency claims about $4.4 \%$ of the total child deaths in the world whereas anaemia is the major reason of post natal death of mothers as well as infants.

Among different techniques to enhance $\mathrm{Zn}$ and $\mathrm{Fe}$ content in rice, ferti-fortification may have effect on increasing farm productivity, enrichment of rice grains with $\mathrm{Zn}$ and $\mathrm{Fe}$. Research on ferti-fortification of rice with $\mathrm{Zn}$ and $\mathrm{Fe}$ has already been started in many developing countries but the extent of $\mathrm{Zn}$ and Fe enrichment in parmal rice and basmati rice at different stages of growth and its absorption in grain needs further investigation.

\section{Effect of $\mathbf{N}$ on production system in rice crop}

\section{Yield and yield contributing parameters}

Nitrogen is the most important component of plant which constitutes about $1-5 \%$ by weight. Nitrogen is mostly absorbed by plant as nitrate $\left(\mathrm{NO}_{3}{ }^{-}\right)$and ammonium $\left(\mathrm{NH}_{4}^{+}\right)$ions. Nitrogen is an integral part of pyroll ring in chlorophyll, which is primary absorber of light energy needed for photosynthesis (Havlin et al., 2011). It plays an important role in optimum vegetative growth, dry matter accumulation and partitioning of proteins in the sink/grains. Singh and Walia (2000) conducted a field experiment and found that application of 120 and $150 \mathrm{~kg} \mathrm{ha}^{-1}$ gave similar grain yield in DSR and TPR but significant superior to $90 \mathrm{~kg}$ ha $^{-1}$. Similarly, Sathiya et al., (2008) found that application of $175 \mathrm{~kg} \mathrm{~N}^{-1}$ resulted in higher yield attributes and grain yield compare to 100 and $125 \mathrm{~kg} \mathrm{~N} \mathrm{ha}^{-1}$. Shivay and Singh (2002) at IARI, New Delhi alsoreported that each unit increase in nitrogen level led to significant increase in growth, yield attributing characters and yield of transplanted basmati rice. At PAU, Kumar et al., (2015) reported that at $125 \%$ of RDN, 10.41 per cent higher grain yield and dry matter produced as compared to $100 \%$ RDN which recorded only 6.54 per cent higher grain yield.Two field experiments were conducted by Lampayan et al., (2010) in Central Luzon at the village of Dapdap in Tarlac Province and at the experimental station of the national soil and Water Resources Research and Development Center, Bureau of Soils and Water management at San Ildefonso in Bulcan province and revealed that yield of aerobic rice obtained with application of $90 \mathrm{~kg} \mathrm{~N} \mathrm{ha}^{-1}$ 
was at par with 120 and $150 \mathrm{~kg} \mathrm{~N} \mathrm{ha}^{-1}$ but significantly higher than yield obtained with $60 \mathrm{~kg} \mathrm{~N} \mathrm{ha}^{-1}$ and control. All yield attributing characters increased significantly with the increase in levels of nitrogen from 40 to 100 $\mathrm{kg} \mathrm{ha}^{-1}$ (Prasad et al., 2003), whereas, an application of $200 \mathrm{~kg} \mathrm{~N}^{-1}$ significantly increased the plant height $(127.3 \mathrm{~cm})$, total number of tillers per hill (16.3), dry matter production $\left(16.0 \mathrm{t} \mathrm{ha}^{-1}\right)$, grain and straw yields (6.5 and $9.5 \mathrm{t} \mathrm{ha}^{-1}$ ) of hybrid rice. While 100 $\mathrm{kg} \mathrm{N}^{-1}$ resulted in highest benefit: cost ratio of crop (Meena et al., 2002). Similarly, Singh et al., (2007) reported that tiller density and panicle length increased significantly with $\mathrm{N}$ application up to $120 \mathrm{~kg} \mathrm{~N} \mathrm{ha}^{-1}$. Gill and Walia (2014) reported that significantly higher grain and straw yield of basmati rice was obtained with 125 percent of recommended dose of nitrogen (90 kg urea ha ${ }^{-1}$ ) over control, 75 and 100 per cent of recommended dose of nitrogen. Sharma et al., (2014) conducted an experiment with different Basmati rice varieties to find out the effect of nitrogen levels on yield components of basmati rice cultivars and they found that nitrogen had significant positive effect and was equally superior in terms of tillers hill $^{-1}$, grains panicle $^{-1}$ and straw yield. Highest number of panicle $\mathrm{m}^{-2}$ was recorded with $160 \mathrm{~kg} \mathrm{~N}^{-}$ ${ }^{1}$ however;differences in filled grain /panicle between 120 and $160 \mathrm{~kg} \mathrm{~N} \mathrm{ha}{ }^{-1}$ were statistically similar.

\section{Milling quality parameters of rice}

Higher levels of $\mathrm{N}\left(60,90 \mathrm{~kg} \mathrm{ha}^{-1}\right)$ decreased the head rice recovery by 3-8 per cent (Rao et al., 1993). Singh et al., (1997) reported that $\mathrm{N}$ fertilization resulted significant increase in rice recovery, protein content in grain, length and breadth of kernel as well as sensory aroma in cooked rice with increase in the $\mathrm{N}$ dose upto $100 \mathrm{kgha}^{-1}$.Cagampang et al., (1996) reported that higher protein rice was more resistant to abrasive milling than low protein rice. Dixit and Gupta (2000) reported that quality parameters like hulling percentage, milling percentage, protein and amylase content increased due to use of FYM and NPK fertilizers. Highest carbohydrate (84.90 q ha $\left.{ }^{-1}\right)$ and protein $\left(7.72 \mathrm{q} \mathrm{ha}^{-1}\right)$ yield of the rice-rice system was obtained when $50 \% \mathrm{~N}$ was substituted through FYM. Rao et al., (2006) reported that the conjuctive use of $25 \% \mathrm{~N}$ through FYM over and above $100 \%$ recommended dose of $\mathrm{N}$ through fertilizer and $60 \mathrm{~kg} \mathrm{ZnSO} \mathrm{ha}^{-1}$ resulted in best quality parameters viz. protein. Mishra et al., (2006) reported that the milling percentage, kernel breadth before and after cooking were significantly higher due to application of organic sources of nitrogen. Kumar et al., (2015) conducted an experiment at PAU and reported that brown rice, white rice and head rice recovery significantly improved with increased doses of $\mathrm{N}, \mathrm{Zn}$ application and foliar $\mathrm{Fe}$.

\section{$\mathrm{Zn}$ and $\mathrm{Fe}$ concentration in paddy grains}

An experiment was conducted in China on two rice varieties i.e. indica 'Zhenong 952' and the japonica 'Bing 98110 ' by Zhang et al., (2008), to study the effect of $\mathrm{N}$ fertilizer on $\mathrm{Fe}$ and $\mathrm{Zn}$ concentration in rice grains. Two rice cultivars fertilized with four rates of urea $(0$, $0.50,1.00$ and $1.50 \mathrm{~g} \mathrm{~N}$ pot $^{-1}$ ) and he found that the optimum application of $\mathrm{N}$ alone on rice crops could increase the concentration of $\mathrm{Fe}$ in the polished rice. Hu-lin et al., (2007) studied the effects of $\mathrm{N}$ fertilizer application on the concentrations of $\mathrm{Fe}$ and $\mathrm{Zn}$ in shoot of rice and the quality of brown rice in two rice varieties i.e. IR64 and IR68144 and they found that in the treatments with $\mathrm{N}$ fertilizer application, the concentrations of $\mathrm{Fe}$ and $\mathrm{Zn}$ in most parts of rice shoot increased compared with control (no $\mathrm{N}$ fertilizer application), they also reported that the concentrations of those microelements in brown rice increased at first and then decreased with further increase of $\mathrm{N}$ 
fertilizer application, reaching the highest at $160 \mathrm{kgha}^{-1}$, at which the $\mathrm{Fe}$ and $\mathrm{Zn}$ concentrations in brown rice increased by $28.96 \%$ and $16.0 \%$ for IR64, and by $22.16 \%$ and $20.21 \%$ for IR68144 compared with control, respectively. Kumar et al., (2016) found in his study of two consecutive years of 2013 and 2014 reported that concentration of $\mathrm{Zn}$ in grains and brown rice significantly increased at higher dose of nitrogen by 25.83 and 27.78 per cent and 25.57 and 27.61 per cent, respectively. Kutman et al., (2010) reported that grain concentrations of $\mathrm{Zn}$ and Fe can be enhanced by increasing the nitrogen (N) supply, and $\mathrm{Zn}$ and $\mathrm{N}$ applications have a synergistic effect on grain $\mathrm{Zn}$ concentration of durum wheat. Cakmak et al., (2010) found that nitrogen nutrition of plants appears to be a critical component for an effective biofortification of food crops with $\mathrm{Zn}$ and $\mathrm{Fe}$ due to several physiological and molecular mechanisms which are under the influence of $\mathrm{N}$ nutritional status. Waters et al., (2009) reported that the plant $\mathrm{N}$ status is an important factor in enrichment of cereal grains with Fe. Increasing molecular evidence is available showing that remobilization from vegetative tissue and translocation into seed of $\mathrm{N}$ and $\mathrm{Fe}$ (as well as $\mathrm{Zn}$ ) is maintained by the similar genetic mechanisms). Kumar et al., (2016) reported that at higher dose of nitrogen application@125\% RDN elevated the grain Fe concentration in grain as well as in brown rice.

In the case of $\mathrm{Zn}$, increasing $\mathrm{N}$ supplies not only significantly enhanced $\mathrm{Zn}$ uptake and root-to-shoot $\mathrm{Zn}$ translocation in wheat, but also increased $\mathrm{Zn}$ retranslocation from flag leaves into grains. Thus, these studies indicate that $\mathrm{N}$ management represents a promising agronomic strategy to improve micronutrient contents in cereal grains. Dash et al., (2010) conducted an experiment to study the effect of organic and inorganic sources of nitrogen on $\mathrm{Zn}$ and $\mathrm{Fe}$ content and their uptake and he found that incorporation of chemical fertilizer enhanced the contents of micronutrients in plants and their uptake in plant and in grain and straw at harvest in comparison to rest of the N sources. Ram et al., (2013) conducted an experiment in BHU on two rice varieties i.e. NDR-359 and HUBR 2-1 with two sources of fertilizer application i.e. $100 \%$ recommended dose of fertilizer (RFD) of NPK through inorganic source and 75\% RFD through inorganic and rest 25\% through FYM and he found that amongst varieties, var. Zn and $\mathrm{Fe}$ content were significantly increased in HUBR 2-1. Fertilizer source as application of 75\% RFD through inorganic and rest through FYM recorded significantly higher $\mathrm{Zn}$ and $\mathrm{Fe}$ content of grain than $100 \%$ RFD through inorganic source.

\section{Effect of soil and foliar application of $\mathrm{Zn}$ on yield and $\mathrm{Zn}$ concentration in grains}

Zinc is one of the most important micronutrients in biological systems, and plays critical role in protein synthesis and metabolism. Several of Zn-binding proteins are transcription factors necessary for gene regulation and necessary for more than a half of enzymes and proteins involved in ion transport. Any decrease in $\mathrm{Zn}$ concentration in human body may result in number of cellular dysfunctions, including a high susceptibility to infectious diseases, retardation of mental development, and stunted growth of children, he also reported thatzinc deficiency is considered to be one of major causes of children death in the world. In wheat, foliar $\mathrm{Zn}$ spray, especially at later growth stages (e.g., early milk stage and dough stage), was very effective in increasing $\mathrm{Zn}$ concentration of both whole grain and also in the endosperm fraction, while soil $\mathrm{Zn}$ applications remained less effective (Cakmak et al., 2010). Jan et al., (2016) said that foliar application of $\mathrm{Zn}$ is much more efficient in grain $\mathrm{Zn}$ accumulation than the soil application. Deposition of 
protein, iron and zinc in rice grains depends on the plethora of interrelated metabolic pathways involved in uptake of $\mathrm{N}, \mathrm{Fe}$ and $\mathrm{Zn}$ from soil, their transport to source tissues such as culms and leaves and mobilization and/or remobilization to developing grains.

Foliar sprays of $\mathrm{Zn}$ at anthesis and milking stage along with soil application of $\mathrm{Zn}$ at the time of transplanting produced higher grain yield as compared to soil application alone and foliar spray alone (Kumar et al., 2015). Phattarakul et al., (2012) conducted an experiment in India and China on zinc application through different methods and he found that the $\mathrm{Zn}$ fertilizer treatments had generally little effect on rice grain yield but as average of 17 trials, soil $\mathrm{Zn}$ application increased grain yield by about $5 \%$ and soil $\mathrm{Zn}$ application had also little effect on grain $\mathrm{Zn}$ but foliar $\mathrm{Zn}$ application consistently increased $\mathrm{Zn}$ concentrations in all trials. In case of un-husked rice, foliar $\mathrm{Zn}$ application increased $\mathrm{Zn}$ concentration by about $66 \%$, but soil $\mathrm{Zn}$ application had only little effect.The combined application of foliar + soil $\mathrm{Zn}$ is beneficial for both grain yield and grain $\mathrm{Zn}$ intake (Gomez-Coronado et al., 2016). Rehman (2012) found that soil and plant $\mathrm{Zn}$ contents increased when $\mathrm{ZnSO}_{4}$ was applied at tillering or panicle initiation than applied at transplanting or without $\mathrm{Zn}$ supply under flooded, alternate wetting and drying and direct seeded aerobic condition. An increase in grain $\mathrm{Zn}$ over basal was 2.5, 2.8 and 2.3 times in flooded, alternate wetting and drying and direct seeded aerobic systems, respectively, when soil $\mathrm{Zn}$ fertilization was applied at panicle initiation. Significant increases in grain yield, straw and grain $\mathrm{Zn}$ contents were observed with foliar application of $\mathrm{Zn}$ as $\mathrm{Zn}$ EDTA and $\mathrm{ZnSO}_{4}$, but the highest increase was observed with Zn-EDTA application. Kumar et al., (2016) in his experiments found that when the zinc was applied through soil + foliar, there was increase of grain $\mathrm{Zn}$ concentration by 36.2 per cent as compared to no $\mathrm{Zn}$ application. Generally, large increases in grain $\mathrm{Zn}$ occur when it is foliarly applied at later stages of plant development. Barua and Saikia (2018) conducted an experiment and found the higher $\mathrm{Zn}$ concentration in grain and brown rice in the treatment of $\mathrm{Zn}$ through soil + foliar applied. Wu et al., (2010) found that higher translocation of $\mathrm{Zn}$ from flag leaves to grains occurred when $\mathrm{Zn}$ had been applied at booting or anthesis stage in a nutrient solution when genotypes with high or low grain $\mathrm{Zn}$ were used. Foliar application of $\mathrm{Zn}(0.5 \% \mathrm{w} / \mathrm{v}$ $\mathrm{ZnSO}_{4}$ ) at panicle initiation was effective in increasing whole grain $\mathrm{Zn}$ contents 2 -fold.

The effect of $\mathrm{Zn}$ on yield and yield components of rice and it was also found that $\mathrm{Zn}$ alone increased the yield significantly over NPK. The agronomic biofortification with the application of $\mathrm{Zn}$ fertilizers to soils and/or leaves can have big short- term improvements in both human health and crop productivity depending on the severity of soil $\mathrm{Zn}$ deficiency. Barua and Saikia (2018) reported highest grain yield when the Zn was applied soil + foliar@0.5\% followed by Soil + seed priming. Foliar application of $\mathrm{Zn}$ sulfate has been often shown superior over Zn-EDTA and over a soil application within an on- going HARVEST PLUS program (www.harvestplus.org) in various developing countries (Cakmak, 2008). Cakmak (2010) reported that soil- and foliar-applied $\mathrm{ZnSO}_{4}$ significantly enhanced grain $\mathrm{Zn}$ concentration in wheat and rice and he found that largest increases in grain $\mathrm{Zn}$ concentration were found in the case of combined application of soil and foliar Zn fertilizers that caused more than a 3-fold increase in grain $\mathrm{Zn}$.

An experiment was conducted at Chiang Mai University, Thailand by Boonchuay et al., (2013) to study the effect of eight foliar $\mathrm{Zn}$ treatments of $0.5 \%$ zinc sulfate $\left(\mathrm{ZnSO}_{4} .7 \mathrm{H}_{2} \mathrm{O}\right)$ which were applied to the rice plant at different growth stages and he found that foliar $\mathrm{Zn}$ increased paddy $\mathrm{Zn}$ concentration 
only when applied after flowering, with larger increases when applications were repeated. The largest increases of up to ten-fold were in the husk, and smaller increases in brown rice Zn. Phattarakul et al., (2012) who showed that a foliar Zn spray applied at late growth to rice grown under field conditions caused a greater increase in grain $\mathrm{Zn}$ than a foliar $\mathrm{Zn}$ spray before flowering stage.

Fe application to increase the yield and nutrient content in grains

\section{Fe concentration in paddy grains}

Nutrient transport into the developing grains depends on exchange between xylem and phloem and remobilization from senescent parts of the mother plant. Hell and Stephan (2003) observed that the accumulation of Fe in grains controlled by a number of processes, including root-cell uptake, root- shoot transfer, and the ability of leaf tissues to load Fe into the vascular phloem that is responsible for delivering $\mathrm{Fe}$ to developing grains via the phloem sap. They found that fortification of seeds or foliage with $\mathrm{Fe}$ for food and feed implies sufficient storage capacities, which could be provided by phytoferritin and constitutive expresses ion of ferritin in tobacco resulted in a 30 per cent increase in leaf $\mathrm{Fe}$ content and about 2 fold elevated $\mathrm{Fe}$ in rice seeds and seed-specific expression even achieved 3 fold Fe levels in rice seeds under regular $\mathrm{Fe}$ nutrition. In a pot experiment on rice crop, Zhang et al., (2009) observed the enrichment of $\mathrm{Fe}$ in rice grains by foliar application of $\mathrm{Fe}$ containing different compounds. They reported that foliar application of Fe-containing solutions like Feamino acid and $\mathrm{FeSO}_{4} .7 \mathrm{H}_{2} \mathrm{O}$ could improve the nutritive levels of rice grains and there was significant increase in $\mathrm{Fe}$ content of rice up to 80 per cent as compared to control.

Three foliar sprays of 1 per cent solution of $\mathrm{FeSO}_{4} \cdot 7 \mathrm{H}_{2} \mathrm{O}$ on rice crop gave a yield of $45 \mathrm{q}$ $\mathrm{ha}^{-1}$ as against $27 \mathrm{q} \mathrm{ha}^{-1}$ obtained with a soil application of $200 \mathrm{~kg} \mathrm{ha}{ }^{-1}$ of $\mathrm{FeSO}_{4} \cdot 7 \mathrm{H}_{2} \mathrm{O}$ reported by Sadana and Nayyar (2000). Dhaliwal et al., (2010) conducted an experiment on loamy sand soil to observe the effect of foliar applied $\mathrm{FeSO}_{4} \cdot 7 \mathrm{H}_{2} \mathrm{O}$ on different rice cultivars. They reported that three foliar application of $\mathrm{FeSO}_{4} \cdot 7 \mathrm{H}_{2} \mathrm{O} @ 0.5$ per cent improved the grain yield in different rice cultivars from 74.4-77.0 $\mathrm{q} \mathrm{ha}^{-1}$ as compared to control which ranged from 67.8$71.4 \mathrm{q} \mathrm{ha}^{-1}$. Similar results were obtained by Aciksoz et al., (2011) in an experiment on biofortification of wheat with Fe through soil and foliar application of nitrogen $(\mathrm{N})$ and $\mathrm{Fe}$ fertilizers. They observed that the plant $\mathrm{N}$ status is an important factor in enrichment of cereal grains with $\mathrm{Fe}$. Molecular evidences showed that remobilization from vegetative tissue and translocation into seed of $\mathrm{N}$ and $\mathrm{Fe}$ is maintained by the similar genetic mechanisms, resulting in a positive correlation between grain $\mathrm{Fe}$ and $\mathrm{N}$ concentrations.

Kumar et al., (2016) reported that foliar application @ $0.5 \%$ increased the $\mathrm{Fe}$ concentration in grain and brown rice both. A field experiment was conducted by Dhaliwal et al., (2009) at research farm, Department of Soil Science, Punjab Agricultural University, Ludhiana on loamy sand soil to observe the biofortification of wheat grains with zinc and Fe. They observed that four foliar sprays of $\mathrm{FeSO}_{4} .7 \mathrm{H}_{2} \mathrm{O} @ 0.5$ per cent at different stages of wheat, starting from maximum tillering, flower initiation, milk and to dough stages, resulted in significant increase in $\mathrm{Fe}$ concentration in wheat grains from 13.1 to 30.3 per cent as compared control. Frossard et al., (2000) observed that foliar fertilization increases crop yield to a greater extent than it increases the Fe content of the grain, it might be the only available fertilization practices that can increase the Fe content of grains. They reported that most of the variation in $\mathrm{Fe}$ content in the seed was due to its genetic component and that environmental effects 
have a small impact, similarly genetic differences in $\mathrm{Fe}$ content of common bean seeds are expressed over different season and in different environmental.

\section{Fe concentration in brown rice}

Zhang et al., (2009) observed enrichment of $\mathrm{Fe}$ in rice grains with different sources of $\mathrm{Fe}$ containing compounds by foliar application. They found that foliar application of $\mathrm{Fe}$ containing solutions could improve the nutritive levels of rice grains. Dhaliwal et al., (2010) conducted a study on loamy sand soil to observe the effect of foliar applied $\mathrm{FeSO}_{4} \cdot 7 \mathrm{H}_{2} \mathrm{O}$ on different rice cultivars. They reported that three foliar application of $\mathrm{FeSO}_{4} .7 \mathrm{H}_{2} \mathrm{O}$ @ 0.5 per cent improved $\mathrm{Fe}$ concentration in brown rice. It ranged from 21.3-28.9 mg kg $\mathrm{mg}^{-1}$ as compared control (17.3$21.2 \mathrm{mg} \mathrm{kg}^{-1}$ ) for different rice cultivars.

A pot experiment was conducted by $\mathrm{Hu}$-lin et al., (2007) to study the effect of different nitrogen fertilizer levels on $\mathrm{Fe}, \mathrm{Mn}, \mathrm{Cu}$ and $\mathrm{Zn}$ concentrations in shoot and grain quality of two rice varieties namely, IR68144 (Fe-dense) and IR64 (Non Fe-dense). They reported that the Fe concentration in brown rice of IR68144 increased up to 41.34 per cent with combination of nitrogen application in contrast to control. Moreover, the increase extent of $\mathrm{Fe}$ concentration in brown rice of IR68144 was much more than that in of IR64 under $\mathrm{N}$ application, which confirmed that IR68144 had a higher ability of $\mathrm{Fe}$ accumulation in grain than IR64. Jin et al., (2007) observed the effect of $\mathrm{Fe}$ and $\mathrm{N}$ mixed fertilizer $\left(0.1\right.$ per cent $\mathrm{FeSO}_{4} \cdot 7 \mathrm{H}_{2} \mathrm{O}$ f.b. 0.4 per cent amino acid f.b. 0.2 per cent urea) on the content of $\mathrm{Fe}, \mathrm{Zn}, \mathrm{Ca}, \mathrm{Mg}$ and protein in brown rice. The results showed that $\mathrm{Fe}$ and $\mathrm{N}$ mixed fertilizer had distinct effects on the accumulation of $\mathrm{Fe}, \mathrm{Zn}, \mathrm{Ca}$, and $\mathrm{Mg}$ and on content of the crude protein in brown rice. They reported that the $\mathrm{Fe}$ concentration in brown rice was increased up to $10.28 \mathrm{mg} \mathrm{kg}^{-1}$ as compared to the control $\left(6.52 \mathrm{mg} \mathrm{kg}^{-1}\right)$ with foliar application of $\mathrm{Fe}$ and $\mathrm{N}$ mixed fertilizer.

\section{Fe concentration in polished rice}

Zhang et al., (2009) reported that there was the highest concentration of $\mathrm{Fe}$ in polished rice $\left(4.7 \mathrm{mg} \mathrm{kg}^{-1}\right)$ of the japonica "Bing 98110" with foliar spray of $\mathrm{FeSO}_{4}$ and it increased significantly (88 per cent) as compared to the control. Zhang et al., (2008) studied $\mathrm{Fe}$ and zinc biofortification in polished rice and accumulation in rice plant as affected by nitrogen fertilization using two rice varieties namely, Zhenong 952 and japonica Bing 98110.They found that there was the highest concentration of $\mathrm{Fe}$ in the polished rice of "Zhenong 952" with the application of $\mathrm{N}$ as compared with no $\mathrm{N}$ supply.In another study conducted by Gregoria et al., (2000), they reported a wide variation of $\mathrm{Fe}$ content in rice grains among rice varieties and also in same varieties. They observed that apart from the effect of $\mathrm{G} \times \mathrm{E}$ interaction, milling process may also affect Fe level in milled rice.

In conclusion, micronutrient malnutrition arising from $\mathrm{Zn}$ and $\mathrm{Fe}$ deficiency is a continuing and serious public health problem in the present world. Several attempts have been made to overcome this malnutrition through diversification of diets, fortification and supplementation. Although food fortification has played an important role in resolve the problem. Increasing the micronutrient density of staple crops, or biofortification, can improve human nutrition on a global scale. Upto some extent, it can be achieved by agronomic fertilization but it is not a long-term sustainable approach in developing countries because some fertilizers (Fe) are costly and dangerous to the environment. But some evidence suggests that nitrogen $(\mathrm{N})$ nutritional status of plants can have a positive impact on root uptake and the 
deposition of $\mathrm{Fe}$ and $\mathrm{Zn}$ in grain or seed. Foliar applications of micronutrients such as $\mathrm{Zn}$ and $\mathrm{Fe}$ are more suitable than the soil application, Due to the rapid overcoming on deficient, easy to use, reduce the toxicity caused by accumulation and prevent the elements stabilization in the soil. There is increasing evidence showing that foliar or combined soil+foliar application of zinc fertilizers and foliar Fe under field conditions are highly effective and very practical way to maximize uptake and accumulation of zinc and $\mathrm{Fe}$ in plants. Zinc-enriched grains are also of great importance for crop productivity resulting in better seedling vigour, denser stands and higher stress tolerance on potentially zinc-deficient soils. Agronomic biofortification strategy appears to be essential in keeping sufficient amount of available zinc in soil solution and maintaining adequate zinc transport to the seeds during reproductive growth stage. Finally, agronomic biofortification is required for optimizing and ensuring the success of genetic biofortification of cereal grains with zinc. In case of greater bioavailability of the grain zinc derived from foliar applications than from soil, agronomic biofortification would be a very attractive and useful strategy in solving zinc and iron deficiency related health problems globally and effectively.

\section{References}

ACC/SCN. 2004. Fifth Report on the World Nutrition Situation. Geneva: United Nations, Administrative Committee on Coordination/ Sub-Committee on Nutrition.

Aciksoz, S. B., Yazici, A., Ozturk, L. and Cakmak, I. 2011. Biofortification of wheat with iron through soil and foliar application of nitrogen and iron fertilizers. Plant Soil349: 215-25.

Barua, D. and Saikia, M. 2018. Agronomic biofortification in rice verities through
Zn fertilization under aerobic condition. Indian J. Agric. Res. 52(1): 89-92.

Boonchuay, P., Cakmak, I.,Rerkasem, B. and Prom-U-Thai, C. 2013.Effect of different foliar zinc application at different growth stages on seed zinc concentration and its impact on seedling vigor in rice. Soil Sci Plant Nutr59: 180-88.

Broadley, M. R., White, P. J., Bryson, R. J., Meacham, M. C., Bowen, H. C., Johnson, S. E., Hawkesford, M. J., McGrath, S. P., Zhao, F. J., Breward, N., Harriman, $M$. and Tucker, $M$. 2006. Biofortification of UK food crops with selenium. ProcNutrSoc65: 169-81.

Cagampang, G. B., Cruz, L. J., Espiritu, S. G., Santiago, R. G. and Juliano, B. O. 1966.Studies on extraction and composition of rice protein. Cereal Chem43: 145-55.

Cakmak, I. 2008. Enrichment of cereal grains with zinc: Agronomic or genetic biofortification. Plant Soil 302: 1-17.

Cakmak, I. 2010.Biofortification of cereals with zinc and iron through fertilization strategy. 19th World Congress of Soil Science, Proc: pp 4-6. 1-6 August, Brisbane, Australia.

Cakmak, I., Kalayci, M., Kaya, Y., Torun, A. A., Aydin, N., Wang, Y., Arisoy, Z., Erdem, H., Yazici, A., Gokmen, O., Ozturk, L. and Horst, W. J. 2010.Biofortification and localization of zinc in wheat grain. J Agric Food Chem58: 9092-102.

Dash, D., Patro, H., Tiwari,R.. C. and Shahid, M. 2010.Effect of organic and inorganic sources of nitrogen on Fe, $\mathrm{Mn}, \mathrm{Cu}$ and $\mathrm{Zn}$ uptake and content of rice grain at harvest and straw at different stages of rice (Oryza sativa) crop growth. AdvApplSci Res 1(3): 3649. 
Depar, N., Rajpar, I., Memon, M.Y., Imtiaz, M., Zia-ul-Hassan. 2011. Mineral nutrient densities in some domestic and exotic rice genotypes. Pak $J$ AgricAgrilEng Vet Sci27: 134-42.

Dhaliwal, S. S., Sadana, U. S., Khurana, M. P. S., Dhadli, H. S. and Manchanda, J.S. 2010. Enrichment of rice grains with zinc and iron through fertifortification. Indian J Fert6: 28-35.

Dhaliwal, S. S., Sadana, U. S., Khurana, M. P. S., Dhadli, H.S. and Manchanda, J. S. 2009.Biofortification of wheat grains with zinc and iron in Typic Ustocherpt soils of Punjab. Indian J Fert5: 13-16 and $19-20$.

Dixit, G. and Gupta, B. R. 2000.Effect of FYM, chemical and biofertilizers on yield and quality of rice and soil properties.J Indian Soc Soil Sci48: 773-80.

Frossard, E., Bucher, M., Machler, F., Mozafar, A. and Hurrell, R. 2000.Potential for increasing the content and bioavailability of $\mathrm{Fe}, \mathrm{Zn}$ and $\mathrm{Ca}$ in plants for human nutrition.J Sci Food Agri80: 861-79.

Gill, J. S. and Walia, S. S. 2014. Quality and grain yield of basmati rice as influenced by different establishment methods and nitrogen levels. Asian $J$ Soil Sci8: 311-18.

Gomez-Coronado, F., Poblaciones, M. J., Almeida, A. S., Cakmak, I. 2016. Zinc $(\mathrm{Zn})$ concentration of bread wheat grown under Mediterranean conditions as affected by genotype and soil/foliar Zn application. Plant Soil. 401:331346.

Graham, R. D., Welch, R. M. and Bouis, H. E. 2001.Addressing micronutrient malnutrition through enhancing the nutritional quality of staple foods: Principles, perspectives and knowledge gaps.AdvAgron70: 77-142.

Gregoria, G. B., Senadhira, D., Htut, T. and
Graham, R. D. 2000.Breeding for trace mineral density in rice. Food Nutr Bull 21: 382-87.

Havlin, J. L., Beaton, J. D., Tisdale, S. L. and Nelson, W. L. 1999. Soil Fertility and fertilizers - An introduction to nutrient management $6^{\text {th }}$ Ed. Prentice hall, New Jersey.

Hell, R. and Stephan, U. W. 2003. Iron uptake, trafficking and homeostasis in plants. Planta216: 541-51.

Hu-lin, H., Zhang, W. Y., Xiao-e, Y., Ying, F. and Yong, W. C. 2007. Effects of different nitrogen fertilizer levels on $\mathrm{Fe}, \mathrm{Mn}, \mathrm{Cu}$ and $\mathrm{Zn}$ Concentrations in shoot and grain quality in rice (Oryza sativa L.). Rice Sci1., 4: 289-94.

IRRI (International Rice Research Institute). 2006. High-iron and zinc rice. (Online) Available: http://www.knowledgebank. irri.org/ factSheets/OtherResources/Health and Nutrition/fs Fe and Zn.pdf.

Jan, M., Anwar-ul-Haq, M., Tanveer-ul-Haq, A. A., Wariach, E.A. 2016. Evaluation of soil and foliar applied $\mathrm{Zn}$ sources on rice (Oryza sativa L.) genotypes in saline environments. Int $\mathrm{J}$ Agricul Biol. 18:643-648.

Jin, Z., Liang-Huan, W. and Min-Yan, W. 2007. Effect of iron and nitrogen mixed fertilizers on the content of $\mathrm{Fe}$, $\mathrm{Zn}, \mathrm{Ca}, \mathrm{Mg}$ and protein in brown rice. J Agro EnviSci 1(Abstr).

Kumar, D., Uppal, R. S., Sharma, S. and Dhaliwal, S. S. 2015. Effect of $\mathrm{N}$ levels, $\mathrm{Zn}$ application methods and foliar $\mathrm{Fe}$ on grain yield, milling qualities and cooking qualities of rice (Oryza sativa L.). Int. J. Agricult. Stat. Sci. 11(1): 189-195.

Kumar, D., Uppal, R. S., Dhaliwal, S. S. and Ram, H. 2016. Enrichment of rice grains with nitrogen, Zinc and Iron ferti-fortification. Indian J. of Fert. 12(8): 52-57. 
Kutman, U. B, Yildiz, B., Ozturk, L. and Cakmak, I. 2010.Biofortification of durum wheat with zinc through soil and foliar applications of nitrogen. Cereal Chem., 87: 1-9.

Lampayan, R. M., Bouman, B. A. M., Dios, J. L., Espiritu, A. J., Soriano, J. B., Lactaoen, A. T., Faronilo, J. E. and Thant, K. M. 2010. Yield of aerobic rice in rainfed lowlands of the Philippines as affected by nitrogen management and row spacing. Field Crop Res116: 165-74.

Mishra, B. N., Kumar, D. and Shivay, Y. S. 2006.Effect of organic sources on productivity, grain quality and soil health of rice (Oryza sativa L.) wheat (Triticum aestivumL.) cropping system. Proc National Symp on Conservation Agric and Environment. Oct. 26-28. 2006, BHU, Varanasi, p 280.

Pfeiffer, W. H. and McClafferty, B. 2007.HarvestPlus: Breeding crops for better nutrition. Crop Sci47: 88-105.

Phattarakul, N., Rerkasem, B., Li, L. J., Wu, L. H., Zou, C. Q., Ram, H., Sohu, V, S., Kang, B. S., Surek, H., Kalayaci, M., Yazici, A., Zhang, F. S. and Cakmak, I. 2012.Biofortification of rice grain with zinc through zinc fertilization in different countries.Plant Soil361: 131-41.

Prasad, D., Singh, J. P., Singh, J. K. and Bharati, V. 2003.Effect of irrigation and nitrogen on growth and yield of early rice (Oryza sativa L.). RAU J Res 13: 148-50.

Qamar, U. Z., Zubair, A., Muhammad, Y., Muhammad, Z. I., Abdul, K., Shah, F., Safder, B., Ramzani, P. M. A. and Muhammad, N. 2017. Zinc biofortification in rice: Leveraging agriculture to moderate hidden hunger in developing countries. Archives of Agronomy and Soil Sci. DOI:
10.1080/03650340.2017.1338343.

Ram, U. S., Srivastava, V. K., Hemantaranjan, A., Sen, A., Singh, R. K., Bohra, J. S. and Shukla, U. 2013.Effect of $\mathrm{Zn}, \mathrm{Fe}$ and FYM application on growth, yield and nutrient content of rice.Oryza50(4): 351-57.

Rao, K. S., Moorthy, B. T. S., Lod, S. B. and Sahoo, K. 1993.Effect of graded levels of nitrogen on yield and quality of different varieties of scented rice.Indian J AgricSci63: 467-72.

Rao, S. A. V., Prasad, P. V. N. and Venkateswarlu, B. 2006. Synergistic influence of nitrogen and zinc on grain yield and quality of rice (Oryza sativa L.). Proc National Symp on Conservation Agriculture and Environment. Oct. 26-28. 2006, BHU, Varanasi. Pp 181-82.

Rehman, H., Farooq, M. and Basra, S. M. A. 2012. High grain $\mathrm{Zn}$ content results from increased $\mathrm{Zn}$ supply and remobilization during grain filling in water saving rice cultivation. In: Abstracts of 14th Congress of Soil Science, 12-15 March, 2012, Lahore, Pakistan

Sadana, U. S. and Nayyar, V. K. 2000. Amelioration of iron deficiency in rice and transformations of soil iron in coarse textured soils of Punjab. $J$ Plant Nutr., 23: 2061-69.

Sathiya, K., Sathiya, M. K. and Martin, G. J. 2008.Effect of nitrogen levels and split doses on the productivity of aerobic rice. Res on Crops9(3): 52730.

Sharma, R., Gangwar, R. K., Yadav, V. and Kumar, R. 2014. Response of basmati rice (Oryza sativa) cultivars to graded nitrogen levels under transplanted condition. Int J Res Appl, Natu Social Sci2(9): 33-38.

Shivay, Y. S. and Singh, S. 2002.Effect of 
planting geometry and nitrogen levels on growth, yield and nitrogen use efficiency scented hybrids rice (Oryza sativa L.).Indian J Agron48: 42-44.

Singh, G. and Walia, S. S. 2010. Influence of FYM, brown manuring and levels of nitrogen on yield and soil properties of direct seeded and transplanted rice. Geobios37: 210-16.

Singh, M. V., Tripathi, H. N. and Tripathi, H. P. 1997.Effect of nitrogen and planting date on yield and quality of scented rice (Oryza sativa). Indian $J$ Agron42(4): 602-06.

Singh, Y., Gupta, R. K., Singh, B. and Gupta, S. 2007. Efficient management of fertilizer nitrogen in wet direct-seeded rice (Oryza sativa L.) in North West India. Indian J AgricSci77: 561-64.

Vennila, C., Jayanthi, C. and Nalini, K. 2007.Nitrogen management in wet seeded rice.Agric Rev28(4): 270-76.

Wang, Y. H., Xue, Y. B. and Li, J. Y. 2005.Towards molecular breeding and improvement of rice in China.Trends Plant Sci10: 610-14.

Wangstrand, H., Eriksson, J. and Oborn, I. 2006.Cadmium concentration in winter wheat as affected by nitrogen fertilization.European $J$ Agrondoi: 10.1016/ j.eja.2006.09.010.

Waters, B. M., Uauy, C., Dubcovsky, J. and Grusak, M. A. 2009. Wheat (Triticum aestivum) proteins regulate the translocation of iron, zinc, and nitrogen compounds from vegetative tissues to grain. $J$ Exp Bot60: 4263-74.

Welch, R. M. and Graham, R. D. 2004.Breeding for micronutrients in staple food crops from a human nutrition perspective. J Exp Bot 55: 353-64.

World Health Organization, 2007. UNICEF India, Children Issues Global Database on Child Growth and Malnutrition in United Nations Administrative Committee on Coordination/Sub-Committee on Nutrition, Low Birth Weight, Nutrition Policy, Pp 18. http://www.who.int/nutgrowthdb/en/.

Wu, C., Lu, L. L., Yang, X. E., Feng, Y. Y., Wei, Y. Y., Hao, H. L. L., Stoffella, P. J. and He, Z. L. 2010. Uptake, translocation, and remobilization of zinc absorbed at different growth stages by rice genotypes of different Zn densities. J Agric Food Chem58: 6767-73.

Zhang, J., Wang, M. Y. and Wu, L. H. 2009. Can foliar iron-containing solutions be a potential strategy to enrich iron concentration of rice grains (Oryza sativa L.)? ActaAgrScand B - Soil Plant Sci59: 389-94.

Zhang, J., Wu, L. H. and Wang, M. Y. 2008. Iron and zinc biofortification in polished rice and accumulation in rice plant (Oryza sativa L.) as affected by nitrogen fertilization. ActaAgrScand B - Soil Plant Sci58: 267-72.

\section{How to cite this article:}

Dipender Kumar, S.S. Dhaliwal, R.K. Naresh and Amit Salaria. 2018. Agronomic Biofortification of Paddy through Nitrogen, Zinc and Iron Fertilization: A Review. Int.J.Curr.Microbiol.App.Sci. 7(07): 2942-2953. doi: https://doi.org/10.20546/ijcmas.2018.707.344 